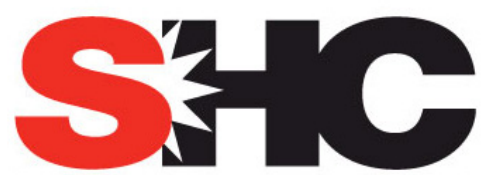

SOLAR HEATING \& COOLING PROGRAMME INTERNATIONAL ENERGY AGENCY
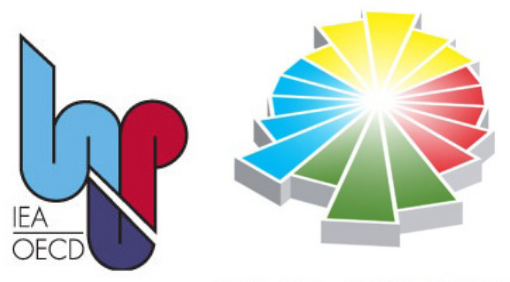

SOLAR + HEAT PUMP

\title{
Models of Sub-Components and Validation for the IEA SHC Task 44 / HPP Annex 38 \\ Part E: Storage models
}

\section{A technical report of subtask $C$}

Report C2 Part E - Final Draft

Date: March 7, 2013

By Sunliang Cao ${ }^{1}, \mathrm{Kai}_{\mathrm{Siren}}{ }^{1}$, Andreas Heinz $^{2}$, Sebastian Bonk ${ }^{3}$

${ }^{1}$ Institution: HVAC technology, Department of Energy Technology, School of Engineering, Aalto University, PO Box 14400, FI-00076 Aalto, Finland

Phone: +358 947023596

Fax: +358947023724

E-mail: sunliang.cao@aalto.fi

${ }^{2}$ Institution: Institue of Thermal Engineering, Graz University of Technology, Inffeldgasse 25b, A-8010 Graz, Austria

Institution: Institute of Thermodynamics and Thermal Engineering (ITW), Research and Testing Centre for Thermal Solar Systems (TZS), University of Stuttgart, Pfaffenwaldring 6, 70550 Stuttgart, Germany 


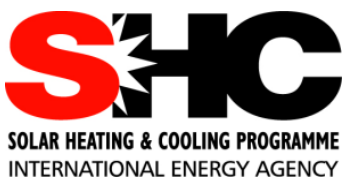

\section{IEA Solar Heating and Cooling Programme}

The International Energy Agency (IEA) is an autonomous body within the framework of the Organization for Economic Co-operation and Development (OECD) based in Paris. Established in 1974 after the first "oil shock," the IEA is committed to carrying out a comprehensive program of energy cooperation among its members and the Commission of the European Communities.

The IEA provides a legal framework, through IEA Implementing Agreements such as the Solar Heating and Cooling Agreement, for international collaboration in energy technology research and development (R\&D) and deployment. This IEA experience has proved that such collaboration contributes significantly to faster technological progress, while reducing costs; to eliminating technological risks and duplication of efforts; and to creating numerous other benefits, such as swifter expansion of the knowledge base and easier harmonization of standards.

The Solar Heating and Cooling Programme was one of the first IEA Implementing Agreements to be established. Since 1977, its members have been collaborating to advance active solar and passive solar and their application in buildings and other areas, such as agriculture and industry. Current members are:

$\begin{array}{lll}\text { Australia } & \text { Finland } & \text { Singapore } \\ \text { Austria } & \text { France } & \text { South Africa } \\ \text { Belgium } & \text { Italy } & \text { Spain } \\ \text { Canada } & \text { Mexico } & \text { Sweden } \\ \text { Denmark } & \text { Netherlands } & \text { Switzerland } \\ \text { European Commission } & \text { Norway } & \text { United States } \\ \text { Germany } & \text { Portugal } & \end{array}$

A total of 49 Tasks have been initiated, 35 of which have been completed. Each Task is managed by an Operating Agent from one of the participating countries. Overall control of the program rests with an Executive Committee comprised of one representative from each contracting party to the Implementing Agreement. In addition to the Task work, a number of special activitiesMemorandum of Understanding with solar thermal trade organizations, statistics collection and analysis, conferences and workshops - have been undertaken.

Visit the Solar Heating and Cooling Programme website - www.iea-shc.org - to find more publications and to learn about the SHC Programme. 
Current Tasks \& Working Group:

Task $36 \quad$ Solar Resource Knowledge Management

Task $39 \quad$ Polymeric Materials for Solar Thermal Applications

Task $40 \quad$ Towards Net Zero Energy Solar Buildings

Task $41 \quad$ Solar Energy and Architecture

Task $42 \quad$ Compact Thermal Energy Storage

Task $43 \quad$ Solar Rating and Certification Procedures

Task $44 \quad$ Solar and Heat Pump Systems

Task $45 \quad$ Large Systems: Solar Heating/Cooling Systems, Seasonal Storages, Heat Pumps

Task $46 \quad$ Solar Resource Assessment and Forecasting

Task $47 \quad$ Renovation of Non-Residential Buildings Towards Sustainable Standards

Task $48 \quad$ Quality Assurance and Support Measures for Solar Cooling

Task $49 \quad$ Solar Process Heat for Production and Advanced Applications

Completed Tasks:

Task 1

Task 2

Task 3

Task 4

Task 5

Task 6

Task 7

Task 8

Task 9

Task 10

Task 11

Task 12

Task 13

Task 14

Task 16

Task 17

Task 18

Task 19

Task 20

Task 21

Task 22

Task 23

Task 24

Task 25

Task 26

Task 27

Task 28

Task 29

Task 31

Task 32

Task 33

Task 34

Task 35

Task 37

Task 38
Investigation of the Performance of Solar Heating and Cooling Systems

Coordination of Solar Heating and Cooling $R \& D$

Performance Testing of Solar Collectors

Development of an Insolation Handbook and Instrument Package

Use of Existing Meteorological Information for Solar Energy Application

Performance of Solar Systems Using Evacuated Collectors

Central Solar Heating Plants with Seasonal Storage

Passive and Hybrid Solar Low Energy Buildings

Solar Radiation and Pyranometry Studies

Solar Materials $R \& D$

Passive and Hybrid Solar Commercial Buildings

Building Energy Analysis and Design Tools for Solar Applications

Advanced Solar Low Energy Buildings

Advanced Active Solar Energy Systems

Photovoltaics in Buildings

Measuring and Modeling Spectral Radiation

Advanced Glazing and Associated Materials for Solar and Building Applications

Solar Air Systems

Solar Energy in Building Renovation

Daylight in Buildings

Building Energy Analysis Tools

Optimization of Solar Energy Use in Large Buildings

Solar Procurement

Solar Assisted Air Conditioning of Buildings

Solar Combisystems

Performance of Solar Facade Components

Solar Sustainable Housing

Solar Crop Drying

Daylighting Buildings in the 21st Century

Advanced Storage Concepts for Solar and Low Energy Buildings

Solar Heat for Industrial Processes

Testing and Validation of Building Energy Simulation Tools

PV/Thermal Solar Systems

Advanced Housing Renovation with Solar \& Conservation

Solar Thermal Cooling and Air Conditioning

Completed Working Groups:

CSHPSS; ISOLDE; Materials in Solar Thermal Collectors; Evaluation of Task 13 Houses; Daylight Research 


\section{Contents}

Executive Summary

Error! Bookmark not defined.

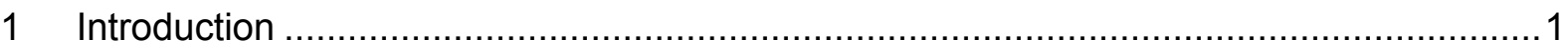

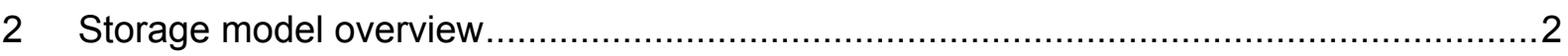

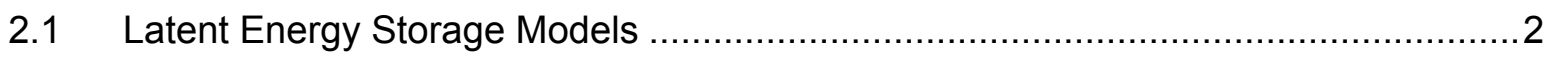

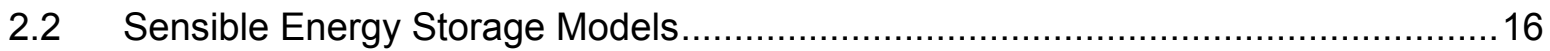

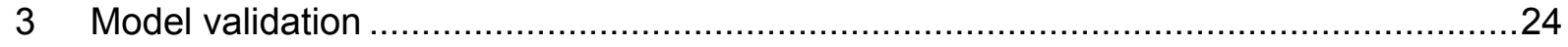

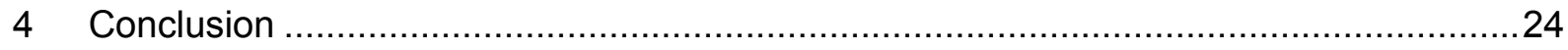

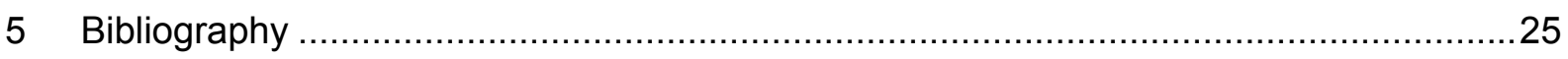

Appendix A - Storage Models Summary Table ...................................................... 27 


\section{Introduction}

In this report, the models for the thermal energy storage systems have been reviewed and listed. The categories of the thermal energy storage models listed in this report are depicted in Figure 1. As shown in Figure 1, the thermal energy storage can be categorized into the latent energy storage (mainly phase change material storage - PCM) and sensible energy storage. For the latent energy storage, there are six representative forms in the practical application: microencapsulated PCM-slurries, capsulated PCM storage modules, multi-layer PCM unit, snow storage, ice storage, and hybrid PCM-sensible storage unit. For the sensible energy storage, there are two representative forms in the practical application: sensible liquids and sensible solids. Furthermore, based on the time scale of the storage, the categories can be divided into short term and seasonal storage. In this report, if the storage module is for seasonal storage, it will be specifically mentioned in the classification. The theoretical principles of different categories of storages are different, and are not the main theme of this report. Representative numerical models have been reviewed and listed according to the categories. In Section 2.1, the latent energy storage models are reviewed and listed, while in Section 2.2, the sensible energy storage models are presented. The validation of these representative models are introduced in Section 3 . The summary table for storage models with respect to certain section is listed in Appendix A. 


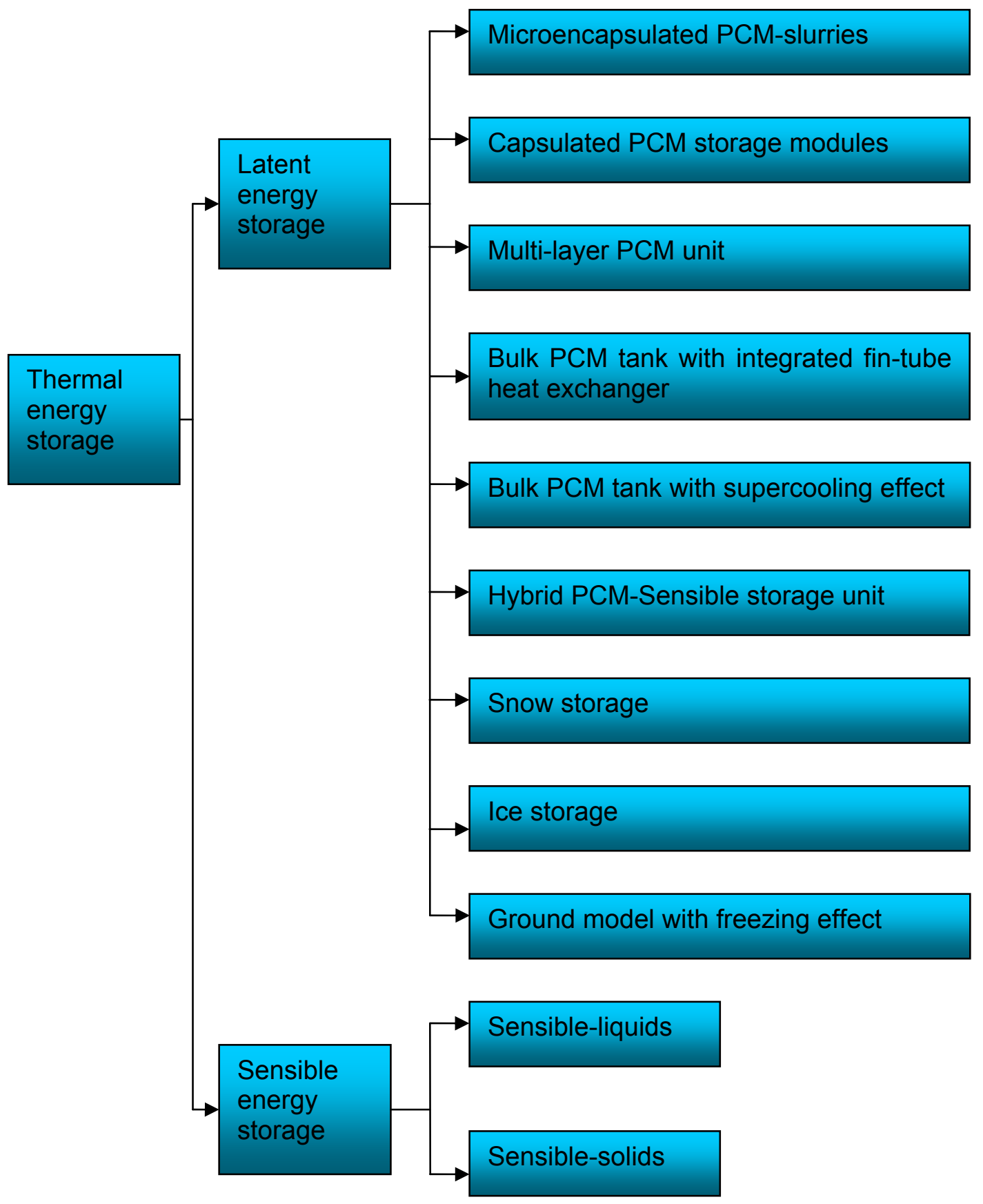

Figure 1 - The categories of thermal energy storage models listed in this report

\section{Storage model overview}

\subsection{Latent Energy Storage Models}

2.1.1 Water \& PCM storage unit model (non-standard TRNSYS Type 840)

- Classification: 
Microencapsulated PCM-slurries; capsulated PCM storage modules; sensible liquids

- Brief description:

Type 840 is a storage model for TRNSYS which is capable of simulating a simple water tank (several double port connections and internal heat exchangers) with integrated cylindrical, spherical of rectangular PCM modules. Different PCM zones with different melting temperatures can be defined in different heights of the tank. Additionally microencapsulated PCM-slurries can be used as storage medium instead of water. A brief schematic of the model is depicted in Figure 2.

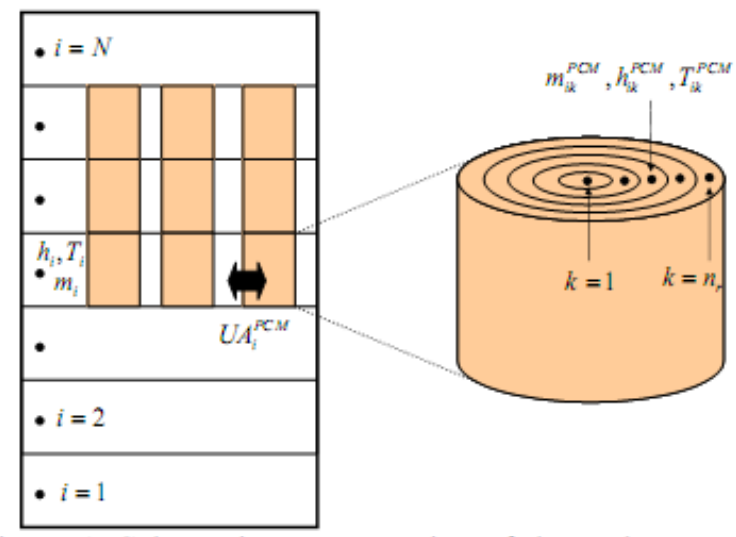

Figure 2 - Brief schematic of PCM storage model for TRNSYS Type 840 (Schranzhofer et al, 2006).

- Phase change solution:

Enthalpy method

- Contact information:

H. Schranzhofer, P. Puschnig, A. Heinz, and W. Streicher

Institute of Thermal Engineering, University of Technology Graz

Inffeldgasse 25/B, A-8010 Graz, Austria

Tel.: (++43-316) 873-7314;

Fax: (++43-316) 873-7305;

E-Mail: hermann.schranzhofer@tugraz.at

- References:

Schranzhofer et al, 2006 
2.1.2 Numerical model for "Packed bed latent heat thermal energy storage system using PCM capsules"

- Classification:

Capsulated PCM storage modules

- Brief description:

The numerical model is for a packed bed storage filled with PCM integrated spherical capsules. The charging and discharging processes are fulfilled by passing the HTF through the packed bed system. The brief schematic is depicted in Figure 3.

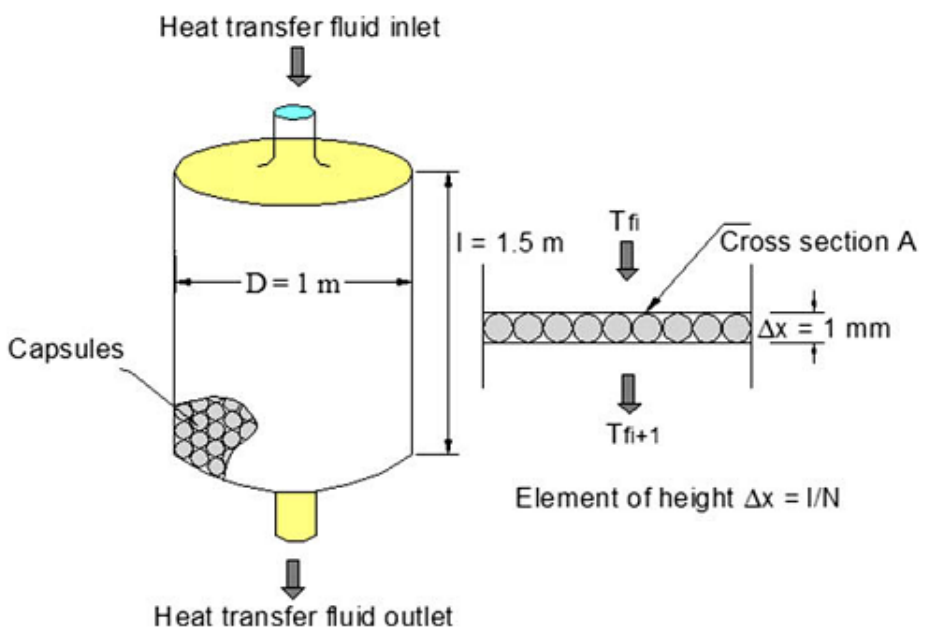

Figure 3 - Brief schematic of PCM storage model for packed bed latent heat thermal energy storage using PCM capsules (Regin et al 2009).

- Phase change solution:

Enthalpy method

- Contact information:

A. Felix Regin ${ }^{1}$, S.C. Solanki, J.S. Saini

Mechanical \& Industrial Engineering Department, Indian Institute of Technology Roorkee, Roorkee 247 667, UA, India

${ }^{1}$ Corresponding author.

Tel.: +91 9818354268;

Fax: +91 1332 285665;

E-mail addresses: felixregin@gmail.com, felixregin@rediffmail.com (A. Felix Regin).

- References: 
Regin et al, 2009

\subsubsection{Numerical model for a multi-layer PCM storage unit}

- Classification:

Multi-layer PCM unit

- Brief description:

The numerical model is for a multi-layer PCM storage, which is composed of parallel PCM plates separated by a rectangular flow passage. The electrical heat sources are embedded inside the PCM plates for storage purpose, while the flow of heat transfer fluid is used for the heat releasing process. Empirical equations of total energy stored and released are also suggested based on the parametric studies. The brief schematic is depicted in Figure 4.

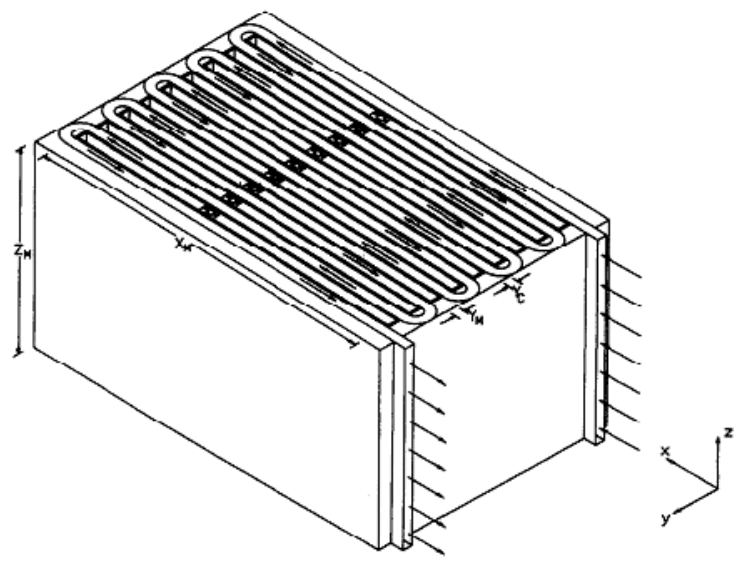

Figure 4 - Brief schematic of PCM storage model for multi-layer PCM storage unit (Brousseau et al 1996).

- Phase change solution:

Enthalpy method

- Contact information:

P. Brousseau, M. Lacroix ${ }^{1}$,

Departement de Genie Mecanique, Universite de Sherbrooke, Sherbrooke, Quebec, Canada JIK 2RI.

${ }^{1}$ Corresponding author.

- References:

Brousseau et al 1996 
2.1.4 Numerical model for latent heat cold storage unit operating under frosting conditions

- Classification:

Multi-layer PCM unit

- Brief description:

This numerical model is for a latent heat cold storage unit composed of parallel plates filled with PCM. The operating purpose is to maintain the air temperature inside the compartment below $265 \mathrm{~K}$ by circulating the warm moist air through the PCM integrated plates. This model comprehensively takes the phase change effect for PCM inside the plate, the frost effect for the exterior surface of the plate and the air flow effect along the plate into consideration.
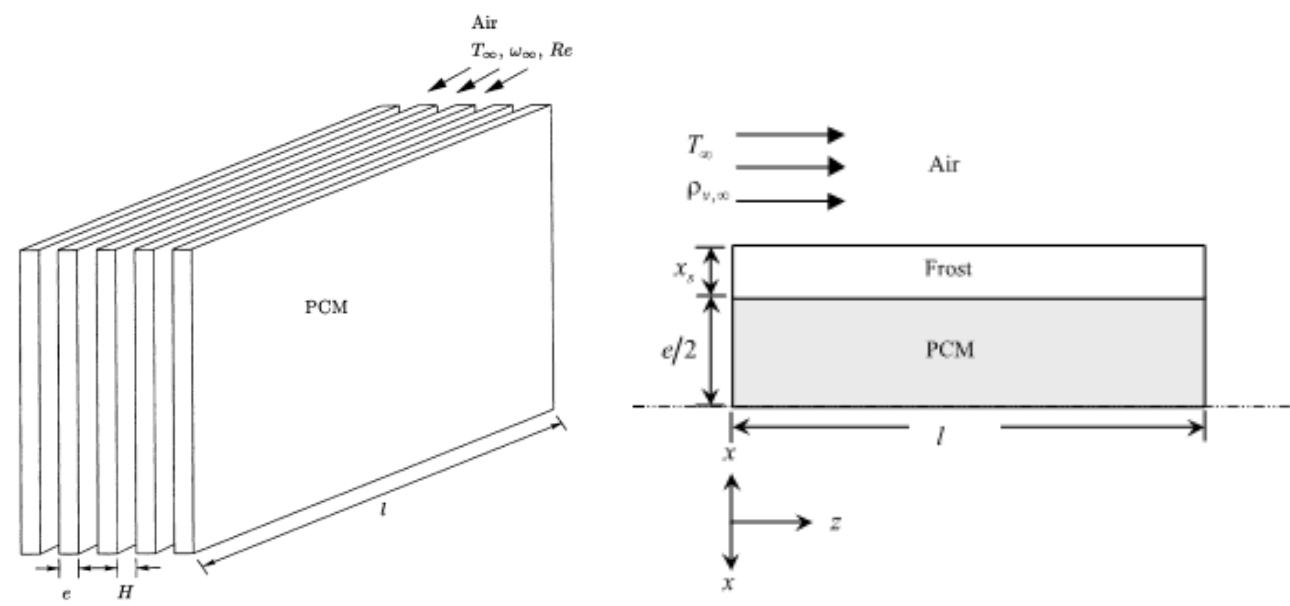

Figure 5 - Brief schematic of numerical model for latent heat cold storage unit operating under frosting conditions (Simard et al 2003).

- Phase change solution:

Enthalpy method

- Contact information:

A. P. Simard, M. Lacroix ${ }^{1}$

Departement de genie mecanique, Universite de Sherbrooke, Sherbrooke, Que., Canada J1K 2R1.

${ }^{1}$ Corresponding author. Tel.: +1-819-821-8000x2145; fax: +1-819-821-7163.

E-mail address: marcel.lacroix@gme.usherb.ca (M. Lacroix).

- References:

Simard et al 2003 
2.1.5 Bulk PCM storage with integrated heat exchanger unit model (non-standard TRNSYS Type 841)

- Classification:

Bulk PCM tank with integrated fin-tube heat exchanger

- Brief description:

Type 841 is a storage model for TRNSYS which is capable of simulatinga rectangular bulk PCM tank that is charged/discharged via an integrated water to air heat exchanger (fin and tube). Heat transfer (conduction) within the PCM is only considered in the direction of the tubes, thus the model is only suitable for heat exchangers with small distances between the tubes.A brief schematic of the model is depicted in Figure 6.

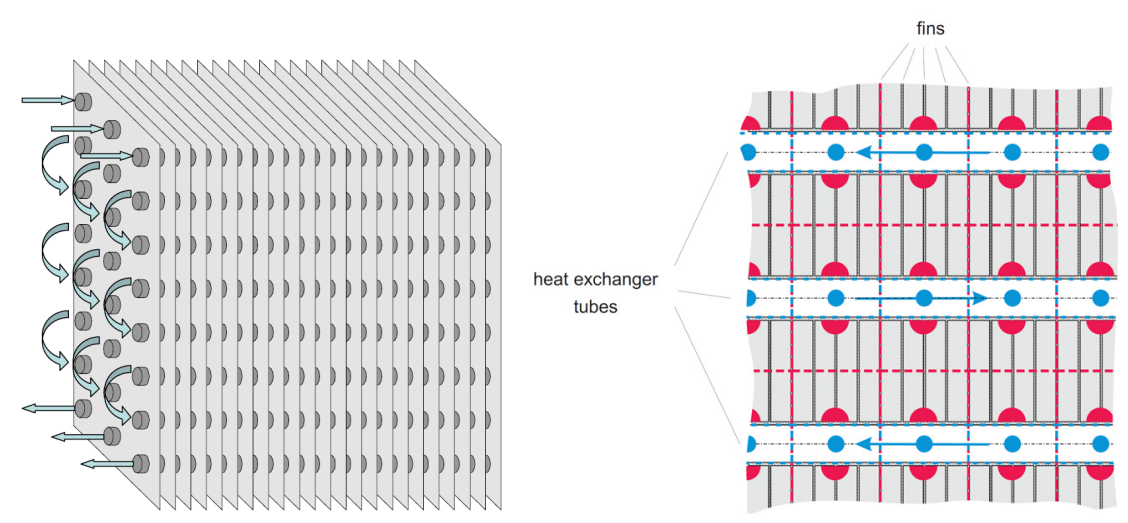

Figure 6-PCM storage model for TRNSYS Type 841; left: fin-and-tube heat exchanger configuration; right: schematic of the nodal network; (Streicher et al., 2008)

- Phase change solution:

Enthalpy method

- Contact information:

A. Heinz

Institute of Thermal Engineering, University of Technology Graz

Inffeldgasse 25/B, A-8010 Graz, Austria

Tel.: (++43-316) 873-7313;

Fax: (++43-316) 873-7305;

E-Mail: andreas.heinz@tugraz.at

- References:

Streicher et al, 2008 


\subsubsection{Bulk PCM storage with supercooling effect (Non-standard TRNSYS Type 185)}

- Classification:

Bulk PCM storage with supercooling effect; seasonal storage

- Brief description:

Type 185 is a storage model for TRNSYS which is capable of treating the supercooling effect for bulk PCM storage, mainly for heat storage. Due to the supercooling effect, the heat storage temperature of liquid storage material can be cooled down to the point below the phase change point without solidification, leading to much less or even no heat losses. Therefore, this kind of PCM storage with noticeable supercooling effect can be used for seasonal storage purposes. A brief schematic of the storage model is depicted in Figure 7.

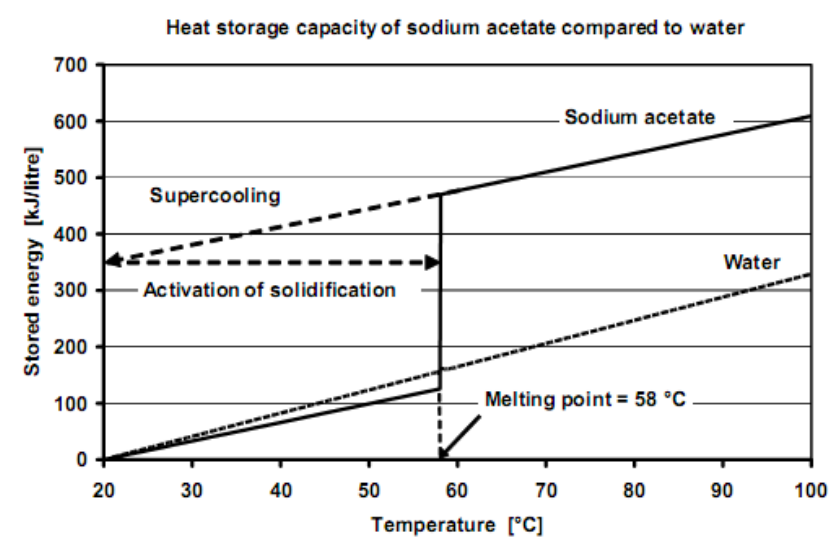

(a)

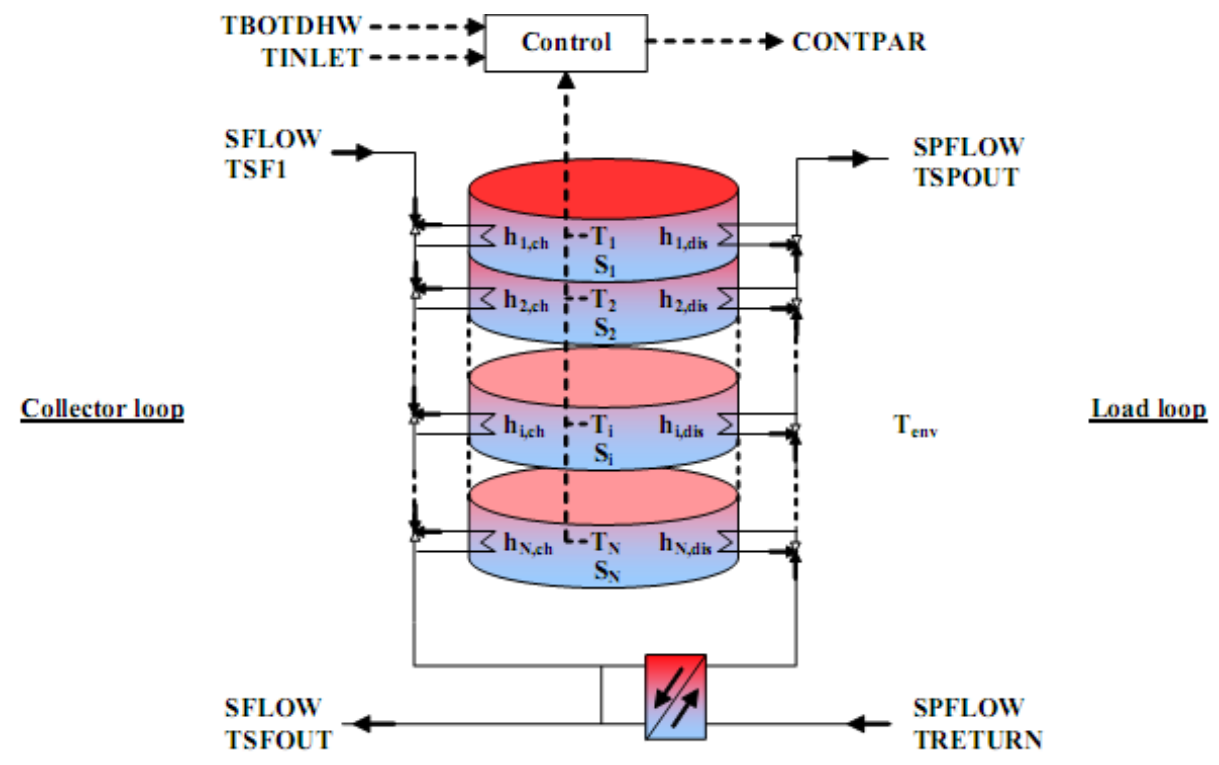

(b)

Figure 7- (a) Supercooling effect of sodium acetate compared to water (b) Brief schematic for TRNSYS Type 185 (Streicher et al, 2008).

- Phase change solution: 
Enthalpy method

- Contact information:

Jørgen M. Schultz

Department of Civil Engineering,

Technical University of Denmark

- References:

Streicher et al, 2008

\subsubsection{A water tank storage with cylindrical PCM module (Type 60PCM)}

- Classification:

Hybrid PCM-Sensible storage unit; capsulated PCM storage modules

- Brief description:

TYPE 60PCM is a new TRNSYS storage model for a DHW tank with cylindrical PCM modules located in vertical position close to the upper base of the water tank. It is further developed from an existing water tank storage model of TYPE 60 in TRNSYS. The brief schematic is depicted in Figure 8.
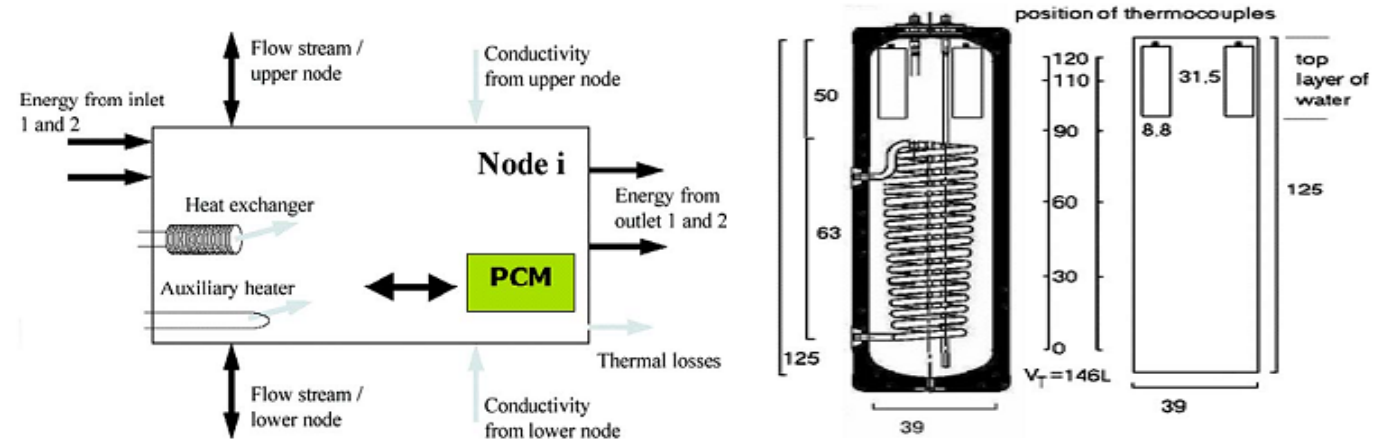

Figure 8 - Brief schematic for water tank storage with cylindrical PCM model Type 60PCM (Ibanez et al 2006).

- Phase change solution:

Enthalpy method

- Contact information:

Manuel Ibanez ${ }^{1}$, Luisa F. Cabeza ${ }^{2,3}$, Cristian Sole ${ }^{2}$, Joan Roca ${ }^{2}$, Miquel Nogues² 
${ }^{1}$ Dept. de Medi Ambient i Ciencies del Sol, Universitat de Lleida, Rovira Roure 191, 25198 Lleida, Spain

${ }^{2}$ Dept. d'Informatica i Eng. Industrial, Universitat de Lleida, Jaume II 69, 25001 Lleida, Spain

${ }^{3}$ Corresponding author.

Tel.: +34 973702742 ;

Fax: +34973702702 .

Email: Icabeza@diei.udl.es (L.F.Cabeza)

- References:

Ibanez et al 2006

2.1.8 Numerical model of water tank storage with PCM modules (cylinders, plates or spheres bed; an extension model of existing TRNSYS Type 60)

- Classification:

Hybrid PCM-Sensible storage unit; capsulated PCM storage modules

- Brief description:

This model is for a water storage tank filled with PCM modules. Different from abovementioned Ibanez et al's model (Section 2.1.7), it considers the hysterisis and subcooling effects, and is also applicable for more PCM shapes, including cylinders, plates and spheres bed. The detailed numerical information of the PCM module has been described in the corresponding reference. The brief schematic is depicted in Figure 9.
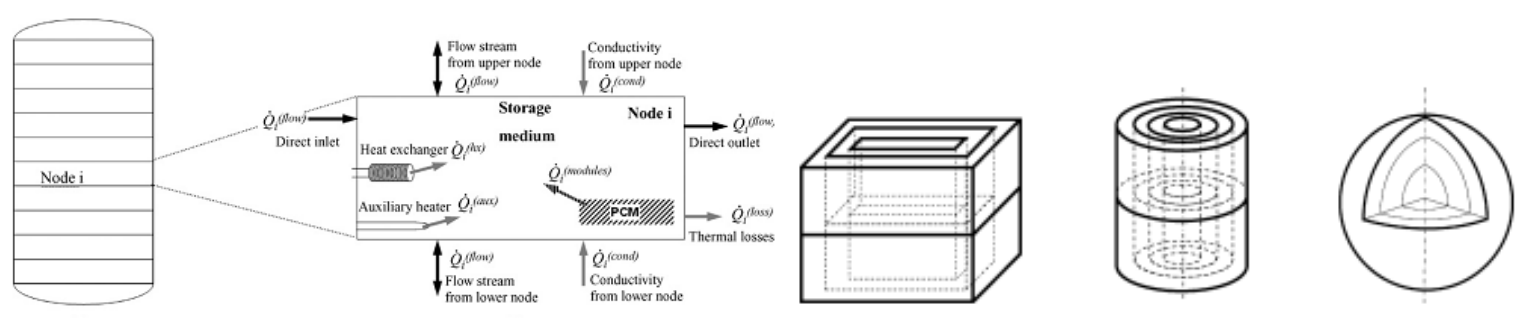

Figure 9 - Brief schematic for numerical model of water tank storage with PCM modules (Bony et al 2007).

- Phase change solution:

Enthalpy method

- Contact information:

Jacques Bony ${ }^{1}$, Stephane Citherlet

Laboratory of Solar Energetics and Building Physics (LESBAT), Applied University of WestSwitzerland (HES-SO/HEIG-VD), 
$\mathrm{CH}-1401$ Yverdon-les-Bains, Switzerland

${ }^{1}$ Corresponding author: Email: jacques@leig-vd.ch (J. Bony)

- References:

Bony et al 2007

2.1.9 Numerical model for a PCM seasonal storage tank

- Classification:

Capsulated PCM storage modules; seasonal storage

- Brief description:

The numerical model is for a seasonal PCM storage tank which is composed of several cylindrical PCM storage cells. Each cell is made of two concentric cylindrical shells, where the PCM is embedded inside the space between two shells and HTF is flowing through the void of inner cylindrical shell. The brief schematic is depicted in Figure 10.

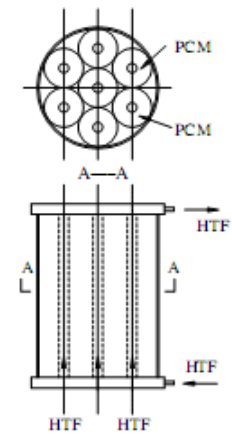

(a) Storage tank unit

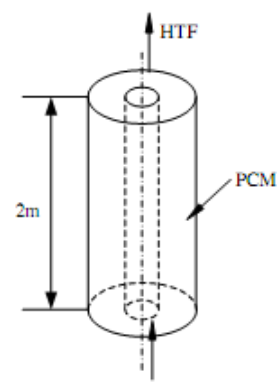

(b) Storage cell

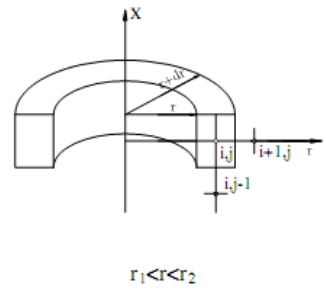

(c) Control volume of storage cell

Figure 10 - Brief schematic for PCM seasonal storage tank (Qi et al 2008).

- Phase change solution:

Enthalpy

- Contact information:

Qi $\mathrm{Qi}^{1}$, Shiming Deng ${ }^{1,3}$, Yiqiang Jiang ${ }^{2}$

${ }^{1}$ Department of Building Services Engineering, The Hong Kong Polytechnic University, Hong Kong SAR, China

${ }^{2}$ Institute of Heap pump and Air conditioning Technology, Harbin Institute of Technology, Harbin, China

${ }^{3}$ Corresponding author. Tel.: +86 852 27665859; fax: +86 85227657198.

E-mail address: besmd@polyu.edu.hk (S. Deng). 
- References:

Qi et al 2008

2.1.10 A simple numerical model for seasonal snow storage

- Classification:

Snow storage; seasonal storage

- Brief description:

The simple numerical model is for a seasonal snow storage excavated in a shallow pit, which is used for seasonal cooling purposes. The storage shape is simplified as a cut cone in the numerical model. It considers both the natural melting and forced melting from the demand. The insulation layers at the top of the storage can be added or not, depending on the simulation requirement. The brief schematic is shown in Figure 11.

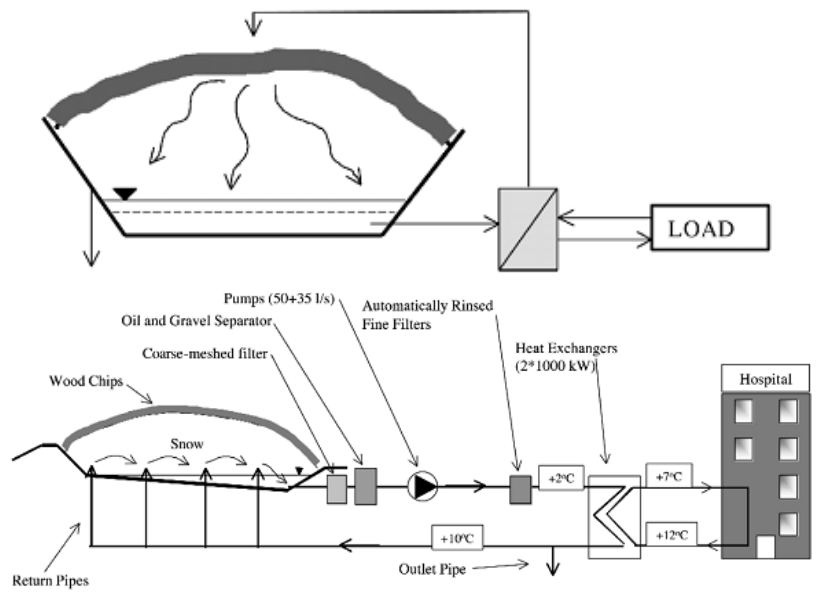

Figure 11. - Brief schematic for seasonal snow storage (Skogsberg et al 2001).

- Phase change solution:

Different treatments under different conditions

- Contact information:

Kjell Skogsberg ${ }^{1}$, Bo Nordell ${ }^{2}$,

Division of Water Resources Engineering, Luleå University of Technology, S-971 87 Luleå, Sweden

${ }^{1}$ Corresponding author. Fax: +46-920-91697.

Email: kjell.skogsberg@sb.luth.se (K. Skogsberg), bo.nordell@sb.luth.se (B. Nordell).

${ }^{2}$ Fax: $+46-920-91697$ 
- References:

Skogsberg et al 2001

\subsubsection{Ice storage tank (Non-standard TRNSYS Type 207)}

- Classification:

Ice storage

\section{- Brief description:}

This non-standard TRNSYS Type models an ice-storage tank for cooling purposes. The basic principle of this storage is to spray the water from the top of the ice and collect the chilled water from the bottom of the tank. A simple effectiveness numerical method is used in this model: the leaving chilled water temperature is kept at $0{ }^{\circ} \mathrm{C}$, when the instantaneous ice inventory exceeds $20 \%$ of the total capacity; otherwise it starts to approach the entering spray water temperature. The brief schematic of this model is depicted in Figure 12.

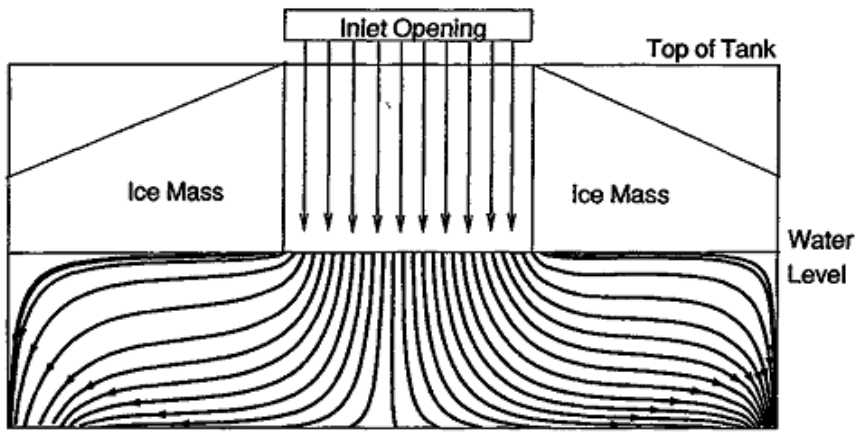

Figure 12 -- The brief schematic of ice storage model (Stewart et al 1994).

- Phase change solution:

Simple effectiveness method

- Contact information:

Modified by Stefan Behschnitt,

http://sel.me.wisc.edu/trnsys/trnlib/library16.htm\#thermalstorage

- References:

TRNSYS Official Website 1996; Stewart et al 1994; Kevin 1994; William 1994.

2.1.12 Ice storage model (non-standard TRNSYS Type 843)

- Classification: 
Ice storage

- Brief description:

Type 843 is a TRNSYS model that enables the simulation of a rectangular ice storage tank with integrated heat exchanger tubes. Ice formation and growth on the tubes and the increasing thermal resistance of the ice is considered by means of a finite difference formulation of the transient fourier equation in cylindrical coordinates. A brief schematic of the model is depicted in Figure 13.

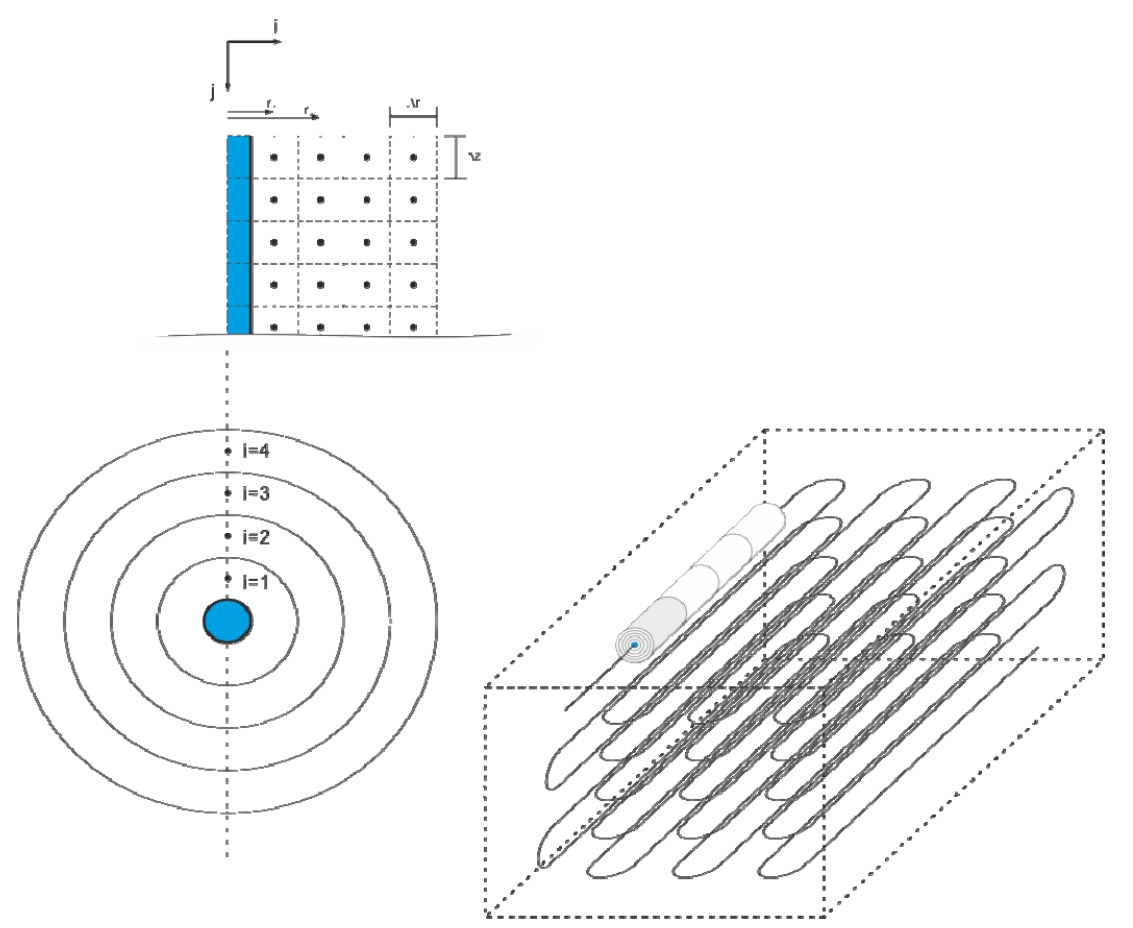

Figure 13 -- The brief schematic of Ice storage model for TRNSYS Type 843 (not published yet).

- Phase change solution:

Enthalpy method

- Contact information:

A. Heinz

Institute of Thermal Engineering, University of Technology Graz

Inffeldgasse 25/B, A-8010 Graz, Austria

Tel.: (++43-316) 873-7313;

Fax: (++43-316) 873-7305;

E-Mail: andreas.heinz@tugraz.at

- References: 
Not published yet

2.1.13 1-D ground numerical model considering the freezing effect of geothermal borehole surroundings

- Classification:

Ground model with freezing effect; Hybrid PCM-Sensible storage unit

- Brief description:

This 1-D ground numerical model is used for simulating the heat transfer process from the ground borehole wall to the ground with possible freezing effect. 1-D is for the radial direction, and is suitable for multiple ground layers at the radial direction. This ground model can be used together with ground borehole models to supplement the ground freezing effect by ground source heat pump systems. The brief schematic of the 1-D ground model has been illustrated in Figure 14.

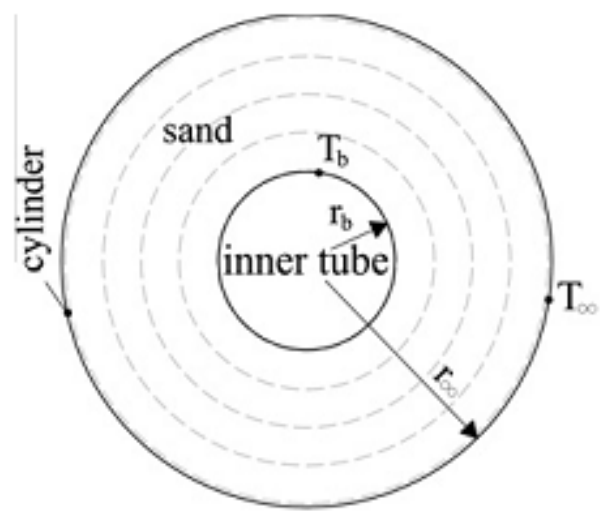

Figure 14-The brief schematic of the 1-D ground model (Eslami-nejad et al 2012).

- Phase change solution:

Effective capacity method

- Contact information:

Parham Eslami-nejad,

Polytechnique Montréal, Département de Génie Mécanique,

Case Postale 6079, Succursale "Centre-Ville",

Montréal, Québec, Canada H3C 3A7

Tel. +1 $5143404711 \times 4381$

Fax: +15143405917

Email: Parham.eslami-nejad@polymtl.ca (P. Eslami-nejad) 
- References:

Eslami-nejad et al 2012

\subsection{Sensible Energy Storage Models}

\subsubsection{Stratified Fluid Storage Tank (TRNSYS Standard Type 4)}

- Classification:

Sensible-liquids

- Brief description:

This standard TRNSYS type models a fluid filled stratified sensible thermal storage tank with two optional auxiliary heaters. It is composed of $N(N \leq 100)$ segments, the number of which determines the degree of stratification. It is also possible to adjust the options of fixed or variable inlets, unequal size nodes, temperature deadband on heater thermostats, incremental loss coefficients, and losses to gas flue of auxiliary heater. The brief schematic of this model is depicted in Figure 15.

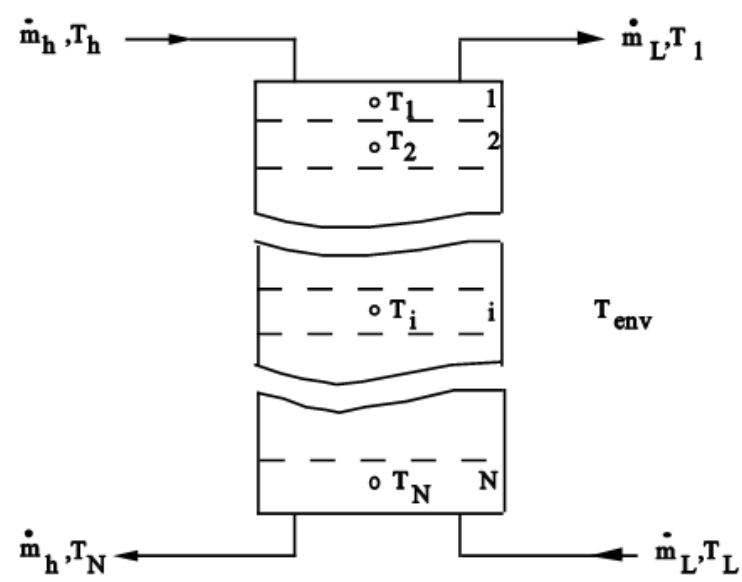

Figure 15. The brief schematic of stratified fluid storage tank model (TRNSYS Documentation; Klein 1976).

- Contact information:

Solar Energy Laboratory, University of Wisconsin-Madison

- References:

TRNSYS documentation; Klein 1976. 


\subsubsection{Detailed Fluid Storage Tank (TRNSYS Standard Type 60)}

- Classification:

Sensible-liquids

\section{- Brief description:}

This standard TRNSYS type models a fluid filled stratified sensible thermal storage tank with two optional auxiliary heaters. It is composed of $N(N \leq 100)$ segments, the number of which determines the degree of stratification. It is also possible to adjust the options of fixed or variable inlets, unequal size nodes, temperature deadband on heater thermostats, incremental loss coefficients, internal submersed heat exchangers, non-circular tanks, horizontal tanks, and losses to gas flue of auxiliary heater. The brief schematic of this model is depicted in Figure 16.
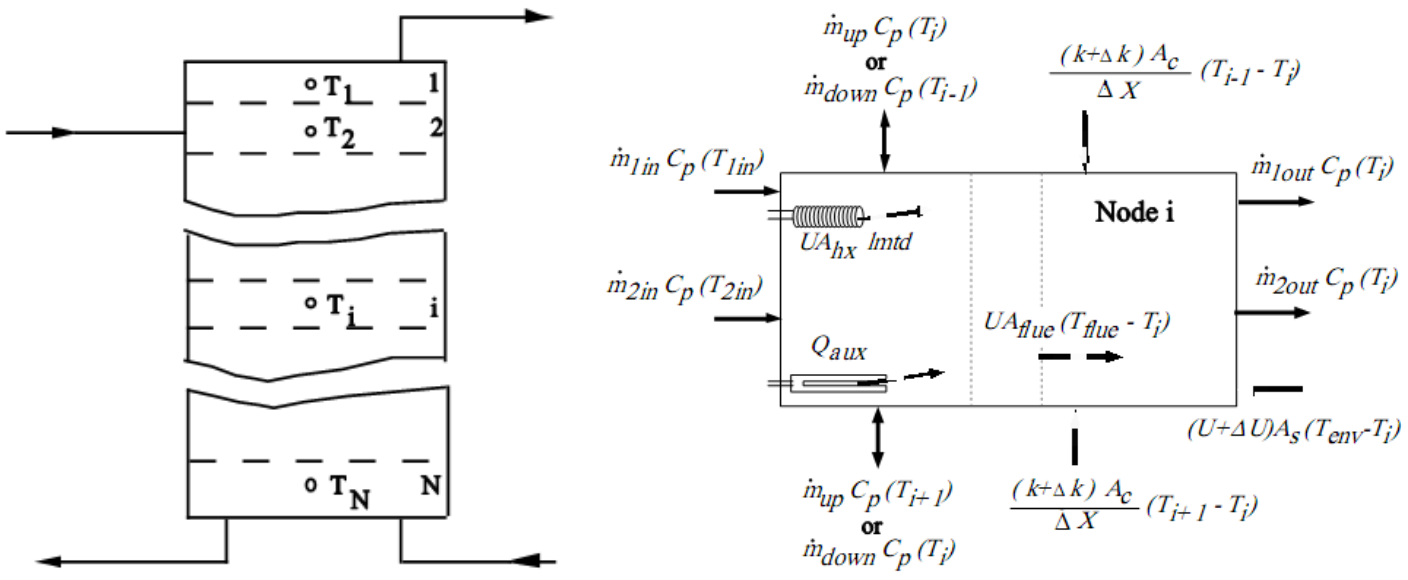

Figure 16. The brief schematic of Detailed Fluid Storage Tank (TRNSYS documentation; Klein 1976; Newton 1995).

- Contact information:

Solar Energy Laboratory, University of Wisconsin-Madison

- References:

TRNSYS documentation; Klein 1976; Newton 1995.

2.2.3 Plug-flow model for stratified water storage tank (TRNSYS Standard Type 38 Algebraic Tank)

- Classification: 
Sensible-liquids

- Brief description:

This Standard TRNSYS type models a stratified fluid storage tank with plug flow method using variable segments of fluid. The advantage of this type than TRNSYS Type 4 or 60 (with fixed node simulation) is that small segments can be used for temperature gradient zone without the necessity to adopt small time steps. This type is suitable for the simulation of highly stratified storage tanks. The brief schematic of this model is shown in Figure 17.

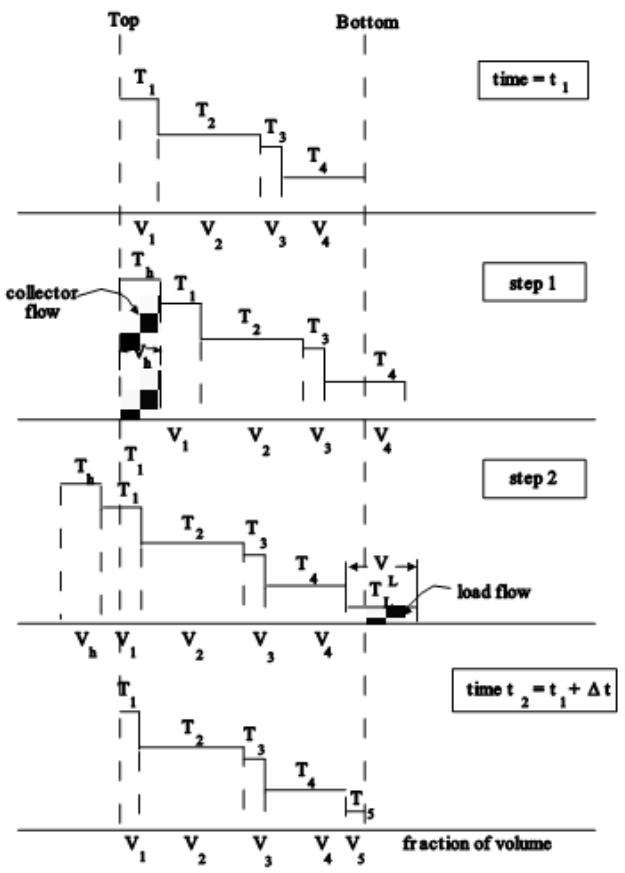

Figure 17. The brief schematic of plug-flow model for stratified water storage tank (TRNSYS documentation; Kuhn et al 1980).

- Contact information:

Solar Energy Laboratory, University of Wisconsin-Madison

- References:

TRNSYS documentation; Kuhn et al 1980.

\subsubsection{Variable Volume Tank (TRNSYS Standard Type 39)}

- Classification:

Sensible-liquids

- Brief description: 
This standard TRNSYS type models a fully-mixed fluid storage tank with a constant crosssectional area but with variable quantity of fluid. Since the overall volume in the storage tank can be variable, the incoming and outgoing flow rates can be different. There is a setting of upper and lower level of volume in the storage. If the instantaneous storage volume is lower than the lower limit, the outgoing flow rate will be forced to meet the lower limit. If the storage volume is higher than the upper limit, either the mode of recirculation of outgoing flow or the mode of diversion of incoming flow can be utilized to maintain the upper limit. The brief schematic of this model is shown in Figure 18.

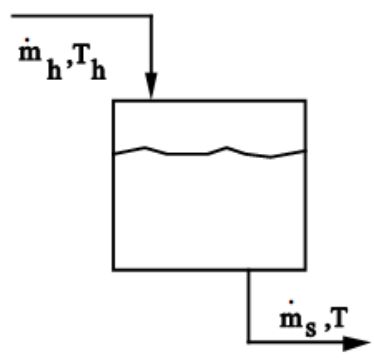

(a)

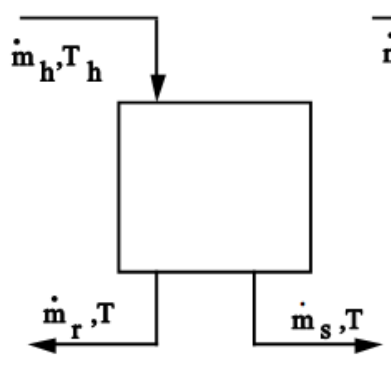

(b)

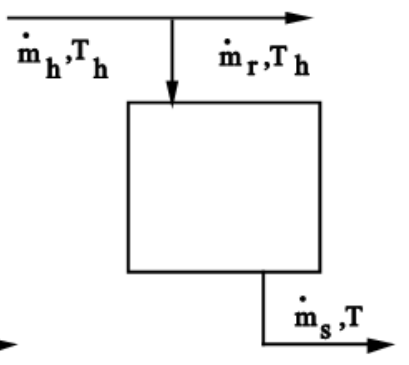

(c)

Figure 18 - The brief schematic of variable volume tank model (TRNSYS documentation).

- Contact information:

Solar Energy Laboratory, University of Wisconsin-Madison

- References:

TRNSYS documentation

\subsubsection{Multiport Store Model (TRNSYS non-standard Type 340)}

- Classification:

Sensible-liquids

- Brief description:

The Type 340 models a stratified fluid storage tank with at most four heat exchangers, an internal electrical auxiliary heater and a maximum of ten times twice connections (double ports) for direct charge and discharge. The MULTIPORT store model is quite universal, so it should be possible to simulate nearly all kinds of stores used for solar thermal systems. For example small stores with a volume of about $0.1 \mathrm{~m} 3$ and three or four heat exchangers, or large stores as directly charged and discharged buffer stores with a volume of about $10 \mathrm{~m} 3$ and up to ten connections for direct charging and discharging. The brief schematic of this model is shown in Figure 19. 

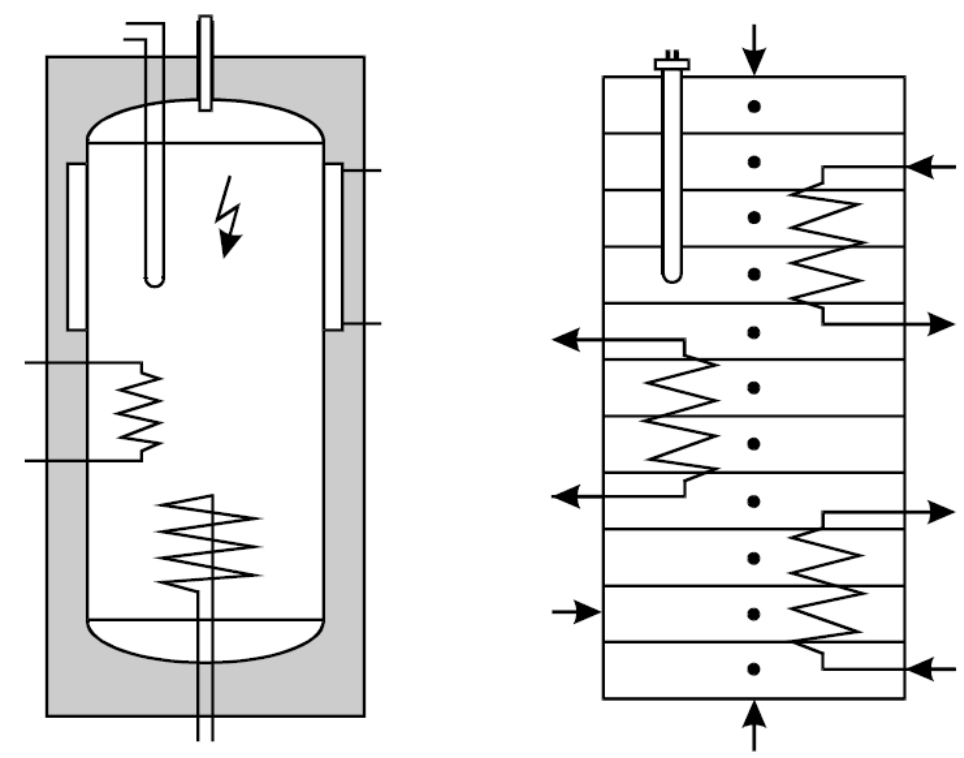

Figure 19. The brief schematic of MULTIPORT Store Model (TRNSYS non-standard Type 340 documentation).

- Contact information:

University of Stuttgart, Institute of Thermodynamics and Thermal Engineering (ITW), Research and Testing Centre for Thermal Solar Systems (TZS), Pfaffenwaldring 6, 70550 Stuttgart, Germany. Email: drueck@itw.uni-stuttgart.de

Officially distributed by TRANSSOLAR Energietechnik $\mathrm{GmbH}$ at:

http://www.transsolar.com/ software/docs/komponenten/komponenten ts de.htm

- References:

TRNSYS non-standard Type 340 documentation; Drück et al, 1996; Drück, 2007.

\subsubsection{Numerical model for a salt gradient solar pond}

- Classification:

Sensible-liquids; Solar pond

- Brief description:

This numerical model is for a salt gradient solar pond, which can be used for the performance prediction, parametric studies, and design purposes. One dimensional finite difference model has been developed to simulate the transient behaviour of the solar pond. The top losses to the ambient air and bottom losses to the ground are both taken into consideration. The detailed numerical model has been described in the reference of (Ouni et al 1998; Ouni et al 2003). The brief schematic of this model is shown in Figure 20. 

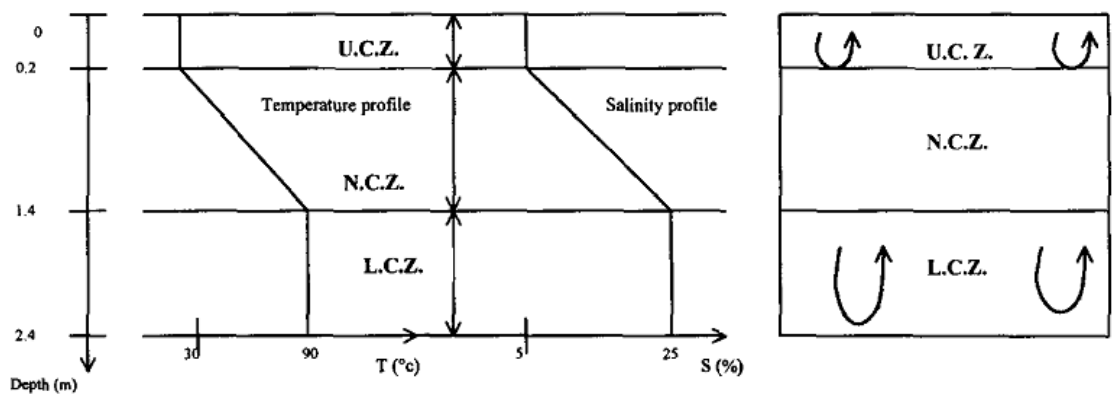

Figure 20 -- the brief schematic of salt gradient solar pond model (Ouni et al 1998).

- Contact information:

M. Ouni, Laboratoire de transfert de chaleur, Departement de physique, Faculté des Sciences, 1060 Tunis, Tunisie;

A. Guizani, INRST Route de Soliman, Hammam Lif, Tunisie;

A. Belguith, Laboratoire de transfert de chaleur, Departement de physique, Faculté des Sciences, 1060 Tunis, Tunisie.

- References:

Ouni et al 1998; Ouni et al 2003.

2.2.7 Numerical model for a solar pond considering the effect of turbidity and wind

- Classification:

Sensible-liquids; Solar pond

- Brief description:

This numerical model is for a solar pond which is based on the double-diffusive model and wind-driven turbulent entrainment model. Thus, the effects of turbidity and wind effects are both taken into consideration. The brief schematic of this model is depicted in Figure 21. 


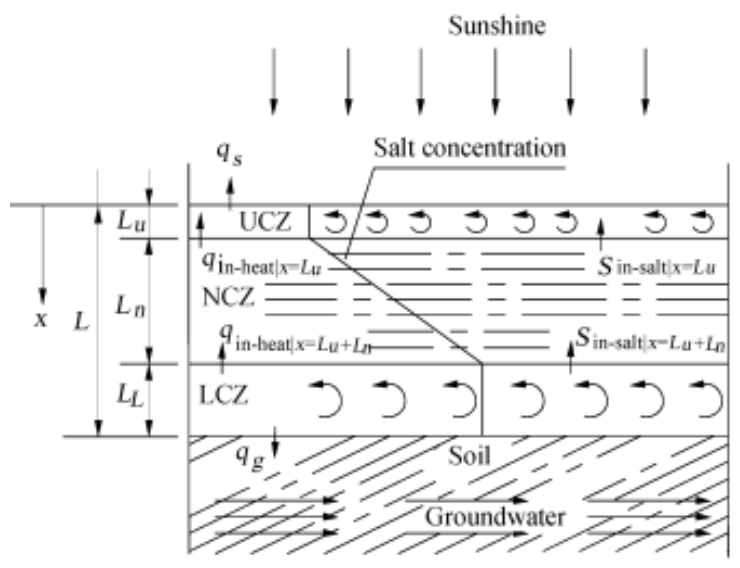

Figure 21 -The brief schematic of numerical model for a solar pond considering the effect of turbidity and wind (Maozhao et al 2006).

- Contact information:

Maozhao Xie ${ }^{1}$, Shaocheng Ge $e^{1,2}$, Wence Sun'1.

${ }^{1}$ Power Engineering Department, Dalian University of Technology, Dalian 116024, China, Email: xmz@dlut.edu.cn

${ }^{2}$ Department of Resource and Environment Engineering, Liaoning Technical University, Fuxin 123000, China, Email: geshaocheng@163.com

- References:

Maozhao et al 2006

\subsubsection{Rock Bed Thermal Storage (TRNSYS Standard Type 10)}

- Classification:

Sensible-solids

- Brief description:

This standard TRNSYS type models a sensible pebble bed (rocks) storage. In the latest TRNSYS 17 version, the hot and cold air flows can flow in two directions through the rock pebble bed storage simultaneously. 


\begin{tabular}{|c|c|c|}
\hline \multirow{5}{*}{ Top } & Segment & 1 \\
\hline & & 2 \\
\hline & & 3 \\
\hline & & : \\
\hline & & : \\
\hline & & $\mathbf{N}$ \\
\hline
\end{tabular}

Figure 22 - The brief schematic of rock bed thermal storage model (TRNSYS documentation; Hughes et al 1976).

- Contact information:

Solar Energy Laboratory, University of Wisconsin-Madison

- References:

TRNSYS documentation; Hughes et al 1976. 


\section{Model validation}

Firstly, for the nine PCM storage models mentioned in Section 2.1, the single PCM storage unit model (Schranzhofer et al, 2006), numerical model of water tank storage with cylindrical PCM module (Ibanez et al 2006), numerical model of water tank storage with various shaped PCM module (Bony et al 2007), and ice storage tank model (TRNSYS Official Website 1996; Stewart et al 1994; Kevin 1994; William 1994) are experimentally validated. The numerical model for seasonal snow storage (Skogsberg et al 2001) is based on a practical project, but the experimental validation is not presented in (Skogsberg et al 2001). The packed bed latent heat thermal energy storage model (Regin et al, 2009), the multi-layer PCM storage unit model (Brousseau et al 1996), and PCM seasonal storage unit model (Qi et al 2008) are not experimentally validated in the corresponding reference.

Secondly, for the sensible storage models, the stratified fluid storage tank model (TRNSYS documentation; Klein 1976), the detailed fluid storage tank model (TRNSYS documentation; Klein 1976; Newton 1995), variable volume tank model (TRNSYS documentation), rock bed thermal storage model (TRNSYS documentation; Hughes et al 1976) are all the TRNSYS standard models, and are experimentally validated. The numerical model of solar pond with effect of turbidity and wind is validated through the comparison of one existing experimental data from (Poplawsky et al 1981), whereas the numerical model of salt gradient solar pond model (Ouni et al 1998, Ouni et al 2003) is validated through the results of simulation and the measured data from the operation of solar pond in University of Texas at El Paso.

\section{Conclusion}

This report reviews and lists the representative storage models commonly used for solar and heat pump applications. Both of the latent and sensible energy storage models are presented. The storage models are relating to specific classifications. The information of model validation is also given in this report. This report contributes to subtask $\mathrm{C}$ of a joint project of IEA SHC T44 and HPP Annex38. The authors acknowledge the collaboration from the participants of this joint project. More information refers to http://www.iea-shc.org/task44/. 


\section{Bibliography}

Bony, J., Citherlet, S., "Numerical model and experimental validation of heat storage with phase change materials," Energy and Buildings, Vol. 39, pp. 1065-1072, 2007.

Brousseau, P., Lacroix, M., "Study of the thermal performance of a multi-layer PCM storage unit," Energy Conversion and Management, Vol. 37, pp. 599-609, 1996.

Cross, K., An Evaluation of Ice and Chilled Water As Thermal Storage Media for Combustion Turbine Inlet Air Cooling Systems, M.S. Thesis, pp 23, University of Wisconsin, Madison, 1994.

Drück, H., "Mathematische Modellierung und experimentelle Prüfung von Warmwasserspeichern für Solaranlagen", Dissertation Universität Stuttgart, Shaker Verlag 2007, ISBN 978-3-8322-6215-0, ISSN 0945-0726

Drück, H., Hahne, E., "Multiport Store Model for TRNSYS". Proceedings of Eurotherm Seminar No. 49, "Physical Models for Thermal Energy Stores", p. 101 - 108, Eindhoven, NL, March 1996

Eslami-nejad, P., Bernier, M., "Freezing of geothermal borehole surroundings: A numerical and experimental assessment with applications," Applied Energy, Vol. 98, pp. 333-345, 2012.

Hughes, P. M., Klein, S. A., and Close, D., "Packed Bed Thermal Storage Models for Solar Air Heating and Cooling Systems", Journal of Heat Transfer, May, 1976.

Ibanez, M., Cabeza, L. F., Sole, C., Roca, J., Nogues, M., "Modelization of a water tank including a PCM module," Applied Thermal Engineering, Vol. 26, pp. 1328-1333, 2006.

Klein, S. A., "A Design Procedure for Solar Heating Systems", Ph.D. Thesis, Department of Chemical Engineering, University of Wisconsin-Madison, 1976.

Kuhn, J. K., VanFuchs, G. F., and Zob A. P., "Developing and Upgrading of Solar System Thermal Energy Storage Simulation Models," Draft Report for DOE, Boeing Computer Services Company, August 31, 1980.

Maozhao, X., Shaocheng, G., and Wence, S., "Numerical Simulation of Double-diffusive Dynamical Model of a Solar Pond Considering the Effect of Turbidity and Wind," Journal of Thermal Science, Vol. 15, pp. 168-174, 2006.

Newton, B. J., "Modeling of Solar Storage Tanks", M.S. Thesis, Department of Mechanical Engineering, University of Wisconsin-Madison, 1995.

Ouni, M., Guizani, A., and Belguith, A., "Simulation of the control of a salt gradient solar pond in the south of Tunisia," Solar Energy, Vol. 75, pp. 95-101, 2003.

Ouni, M., Guizani, A., and Belguith, A., "Simulation of the transient behaviour of a salt gradient solar pond in Tunisia," Renewable Energy, Vol. 14, pp. 69-76, 1998.

Poplawsky, C.J., Incropera, F.P., Viskanta, R., "Mixed Layer Development in a Doublediffusive Thermohaline System," Solar Energy, Vol. 103, pp. 351-359, 1981.

Qi, Q., Deng, S., and Jiang, Y., "A simulation study on a solar heat pump heating system with seasonal latent heat storage," Solar Energy, Vol. 82, pp. 669-675, 2008.

Regin A. F., Solanki S. C., Saini J. S., "An analysis of a packed bed latent heat thermal energy storage system using PCM capsules: Numerical investigation," Renewable Energy, Vol. 34, pp. 1765-1773, 2009. 
Schranzhofer, H., Puschnig, P., Heinz, A., and Streicher, W., "Validation of a trnsys simulation model for pcm energy storages and pcm wall construction elements," Ecostock 2006 - Tenth International Conference on Thermal Energy Storage, June 2, 2006, USA. [Online]. Available:

http://intraweb.stockton.edu/eyos/energy studies/content/docs/FINAL PAPERS/11B$\underline{4 . p d f}$

Simard, A. P., Lacroix, M., "Study of the thermal behavior of a latent heat cold storage unit operating under frosting conditions," Energy Conversion and Management, Vol. 44, pp. 1605-1624, 2003.

Skogsberg, K., Nordell, B., "The Sundsvall hospital snow storage," Cold Regions Science and Technology, Vol. 32, pp. 63-70, 2001.

Stewart, W.E., "Modeling of Ice Filling Process of Rectangular Thermal Energy Storage Tanks with Multiple Ice Maker Openings," American Society of Heating, Refrigerating, and Air-Conditioning Engineers Transactions, Vol. 100, Part II, Atlanta, 1994.

Stewart, W.E., Gute, G.D., Becker, B.R., Misra, A., "Development of a design procedure for thermal energy storage tanks which separate the manufacture from the storage of ice," Final report Research Project 707 for American Society of Heating, Refrigerating, and Air-Conditioning Engineers, Atlanta, 1994.

Streicher, W., Bony, J., Citherlet, St., Heinz, A., Puschnig, P., Schranzhofer, H., Schultz, J.M., 2008. Simulation Models of PCM Storage Units; A Report of IEA Solar Heating and Cooling programme - Task 32 - Advanced storage concepts for solar and low energy buildings; Report C5 of Subtask C, March 2008.

TRNSYS documentation. SEL (Solar Energy Laboratory, Univ. of Wisconsin-Madison), TRANSSOLAR (TRANSSOLAR Energietechnik $\mathrm{GmbH}$ ), CSTB (Centre Scientifique et Technique du Bâtiment), TESS (Thermal Energy Systems Specialists), "TRNSYS 17 A Transient System Simulation Programme Volume 4 Mathematical Reference," the documentations attached in the software package of TRNSYS 17 for the Standard Component Library.

TRNSYS Official Website, Modified by Stefan Behschnitt, “207 ICE STORAGE TANK," June 1996. [Online]. Available:

http://sel.me.wisc.edu/trnsys/trnlib/library16.htm\#thermalstorage

TRNSYS Type 340 (non-standard) documentation :

http://www.transsolar.com/ software/download/de/ts type 340 de.pdf 


\section{Appendix A - Storage Models Summary Table}

\begin{tabular}{|c|c|c|c|c|}
\hline Section & Platform $^{(a)}$ & Classification $^{(\mathrm{b})}$ & Validation $^{(\mathrm{c})}$ & References \\
\hline 2.1 .1 & TRN & MCPS; CPSM; SENL & $\mathrm{Y}$ & Schranzhofer et al, 2006 \\
\hline 2.1 .2 & Open & CPSM & $\mathrm{N}$ & Regin et al, 2009 \\
\hline 2.1 .3 & Open & MLPU & $\mathrm{N}$ & Brousseau et al 1996 \\
\hline 2.1 .4 & Open & MLPU & $\mathrm{Y}$ & Simard et al 2003 \\
\hline 2.1 .5 & TRN & BPHX & $\mathrm{Y}$ & Streicher et al, 2008 \\
\hline 2.1 .6 & TRN & BPSC ; SEAS & $\mathrm{N}$ & Streicher et al, 2008 \\
\hline 2.1 .7 & TRN & HPSU; CPSM & $\mathrm{Y}$ & Ibanez et al 2006 \\
\hline 2.1 .8 & TRN & HPSU; CPSM & $\mathrm{Y}$ & Bony et al 2007 \\
\hline 2.1 .9 & Open & CPSM; SEAS & $\mathrm{N}$ & Qi et al 2008 \\
\hline 2.1 .10 & Open & SNOS; SEAS & $\mathrm{P}$ & Skogsberg et al 2001 \\
\hline 2.1 .11 & TRN & ICES & $\mathrm{Y}$ & $\begin{array}{l}\text { TRNSYS Official Website 1996; Stewart et al 1994; Kevin 1994; } \\
\text { William } 1994\end{array}$ \\
\hline 2.1 .12 & TRN & ICES & $\mathrm{N}$ & Not published yet \\
\hline 2.1 .13 & Open & GFZ; HPSU & $\mathrm{Y}$ & Eslami-nejad et al 2012 \\
\hline 2.2 .1 & TRN & SENL & $\mathrm{Y}$ & TRNSYS documentation; Klein 1976 \\
\hline 2.2 .2 & TRN & SENL & $\mathrm{Y}$ & TRNSYS documentation; Klein 1976; Newton 1995 \\
\hline 2.2 .3 & TRN & SENL & $\mathrm{Y}$ & TRNSYS documentation; Kuhn et al 1980 \\
\hline 2.2 .4 & TRN & SENL & $\mathrm{Y}$ & TRNSYS documentation \\
\hline 2.2 .5 & TRN & SENL & - & $\begin{array}{l}\text { TRNSYS non-standard Type } 340 \text { documentation; Drück et al, 1996; } \\
\text { Drück, } 2007 .\end{array}$ \\
\hline 2.2 .6 & Open & SENL; SP & $\mathrm{Y}$ & Ouni et al 1998; Ouni et al 2003 \\
\hline 2.2 .7 & Open & SENL; SP & $\mathrm{Y}$ & Maozhao et al 2006 \\
\hline 2.2 .8 & TRN & SENS & $\mathrm{Y}$ & TRNSYS documentation; Hughes et al 1976 \\
\hline
\end{tabular}


(a) Platform abbreviation:

\section{TRN: TRNSYS}

Open: no specific platform, only numerical model

(b) Classification abbreviation:

BPHX: Bulk PCM tank with integrated fin-tube heat exchanger

BPSC: Bulk PCM tank with supercooling effect

CPSM: Capsulated PCM storage modules

GFZ: Ground model with freezing effect

MCPS: Microencapsulated PCM-slurries

MLPU: Multi-layer PCM unit

SNOS: Snow storage

ICES: Ice storage

HPSU: Hybrid PCM-Sensible storage unit

SENL: Sensible-liquids

SENS: Sensible-solids

SEAS: Seasonal storage

SP: Salt gradient solar pond

(c) Validation abbreviation:

Y: Yes

$\mathrm{N}$ : No

P: Practical project, but not validated in the corresponding reference 